Lucrările Seminarului Geografic Dimitrie Cantemir

Vol. 45, October 2017, pp. 45-54

http://dx.doi.org/10.15551/lsgdc.v45i0.04

\title{
Assessment of the geomorphological processes in the lower Bic Plane, Republic of Moldova
}

\author{
Angela Canțîrir ${ }^{1}$ Tatiana Bunduc ${ }^{1}$ \\ ${ }^{1}$ Institute of Ecology and Geography, Academy of Sciences of Moldova, Republic of Moldova
}

To cite this article: Canțîr, A. \& Bunduc, T. (2017). Assessment of the geomorphological processes in the lower Bic Plane, Republic of Moldova. Lucrările Seminarului Geografic Dimitrie Cantemir, Vol. 45, pp. 45-54. DOI: 10.15551/lsgdc.v45i0.04

To link to this article: http://dx.doi.org/10.15551/lsgdc.v45i0.04 


\title{
ASSESSMENT OF THE GEOMORPHOLOGICAL PROCESSES IN THE LOWER BIC PLANE, REPUBLIC OF MOLDOVA
}

\author{
Angela Canțîr ${ }^{1}$, Tatiana Bunduc
}

\begin{abstract}
The Lower Bic Plane is located in the south-east part of Moldova, occupying a total area of $2663 \mathrm{~km}^{2}$. Geology, relief, climate, hydrography, vegetation and especially human intervention which occur in this region led to the deployment of geomorphological processes on extremely large surfaces. The most important processes that contribute to land degradation in the Lower Bic Plane are specific to the entire hilly area between Prut and Dniester, and consist of soil erosion, gullies and landslides. For identification, mapping and analyzing these processes were consulted topographic maps (scale 1:25 000), geological maps (scale 1:200 000) and ortophotoplans of 0,5 m resolution (2007 edition), using MapInfo 9 and Arc GIS 9.3 software and also field observations. The spatial distribution of geomorphological processes reveals their higher prevalence in the east and west parts, and lowest in the north and south parts of region. Even though many degraded areas were improved by anti-erosion work, which was performed until 1990, however, have been created conditions that led to the resumption of geomorphological processes.
\end{abstract}

Keywords: geomorphological processes, landslides, gullies

\section{Introduction}

From a geomorphologicalo point of view the Lower Bic Plane is adjacent to four other geomorphological units. The northwestern part is bordered by Codrii Bicului Plateau, the northeastern and eastern part by the Lower Dniester Plane, the south-southeastern part is bordered by the Cogilnic Plane and the south-southwestern part by the Cogilnicul de Mijloc Plateau. The slopes of the basins within the territory of the plane have over $160 \mathrm{~m}$ altitude and the length of the slopes often exceeds 1000 meters. Only the interfluves between Botna Dniester and their tributaries are represented by crests that exceed $160 \mathrm{~m}$ altitude, reaching the maximum altitude of $233.8 \mathrm{~m}$ (in the Puhoi commune, Ialoveni district). Relief formation, its characteristics and relief elements are determined by the distribution and resistance of rocks and their interaction with exogenous factors.

The relief of the plain is sculpted by numerous flowing waters, forming valleys, depressions characteristic of this type of relief (Donisă, Boboc, 1994). Using transversal profiles, it was possible to represent the relief forms on the researched territory. The profile was drawn from NV to SE and comprises the alignment on the Baltata - Valea Colonita interfluves (Figure 1).

\footnotetext{
${ }^{1}$ Institute of Ecology and Geography, AȘM, Lab. of Geomorphology and Ecopedology e-mail: angelamadan87@gmail.com
} 


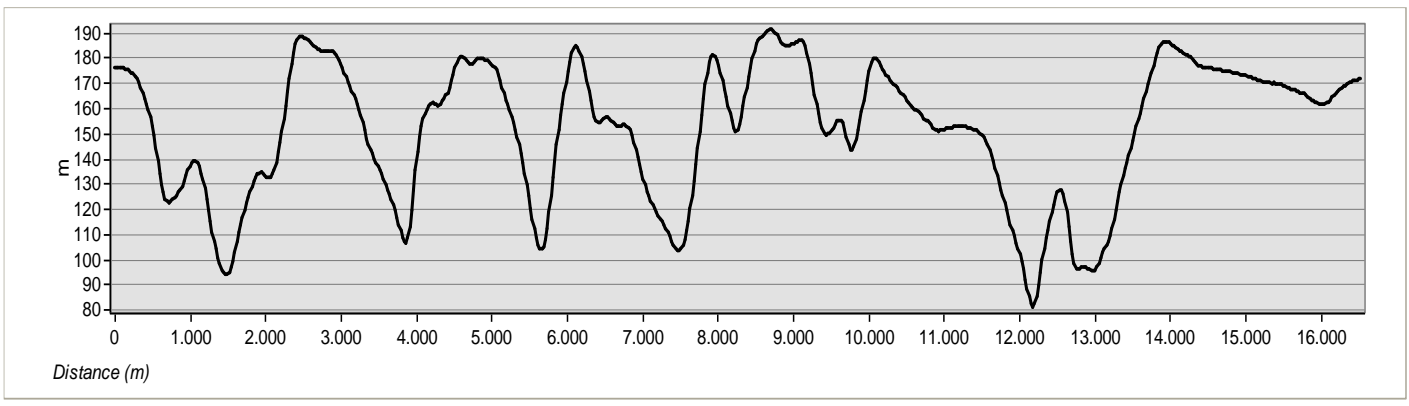

Figure 1. Cross-sectional profile in the NV-SE direction drawn on Bălţata-Valea Coloniţa interfluve.

The relief of the Lower Bic Plane is characterized by low altitudes (50-200 m), with an average altitude of $122.2 \mathrm{~m}$ and a maximum variation of $227.4 \mathrm{~m}$ between the maximum (233.8 $\mathrm{m}$ - Puhoi locality, Puhoi hill) and minimum (6.4 $\mathrm{m}$ at the confluence of the Bic and Dniester rivers) values (Figure 2).

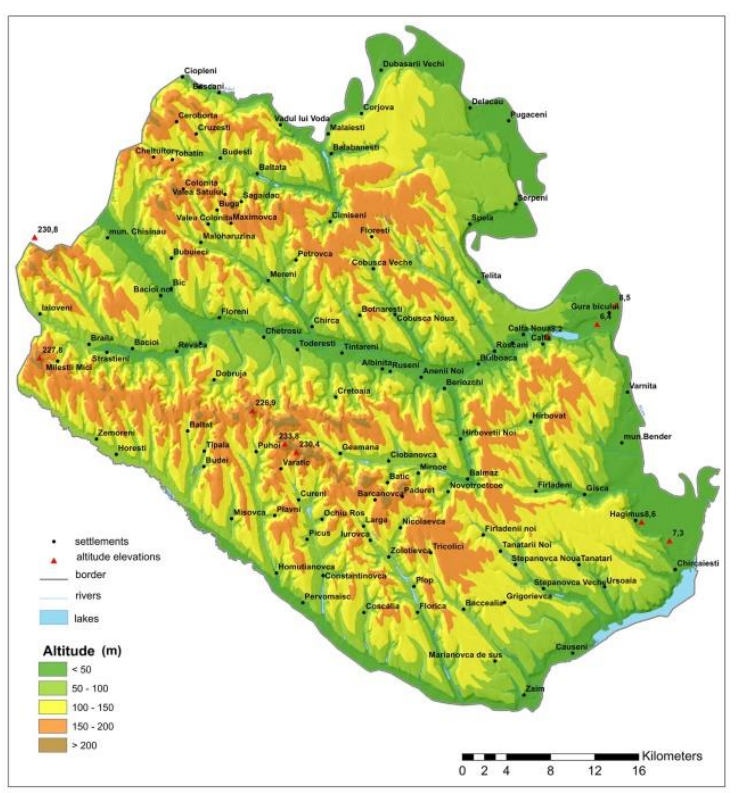

Figure 2. Hypsometry

The hypsometric map highlight 5 altitude steps and the histogram of the surfaces by hypsometric classes (Figure 3) represents the same 5 classes that will show their percentage in the total area of the territory (Canţîr,2016).

Overall, the highest surface in the plain is occupied by the altitudes ranging between 100-150 m (35\% of the area), represented by the lower part of the hillsides. The altitudes ranging between 150-200 m occupy the middle and upper third of the slopes and reach a total percentage of $18 \%$. The slope is a very important indicator in relief analysis, being one of the key factors in the development of geomorphological processes, especially the processes related to the shift on the slope. Analyzing the slope map (Figure 4) it is observed that the slopes under $1^{\circ}$ occupy $18.41 \%$ of the territory and spread in the river beds, very well represented in the Dniester floodplain (in this part are the largest floodplains).

A morphometric feature no less important is the slope orientation (Figure 5). The slope orientation is important from the point of view of the thermal action of the solar rays on these slopes. This aspect has a zonal character and has an indirect influence on the occurrence of some slope processes (the North directional slopes, for example are more shaded, therefore they are more damp and cooler and have a substrate with strong moisture, that is why they could be more prone to certain geomorphological processes), (Popuşoi, Canţîr, 2012). 


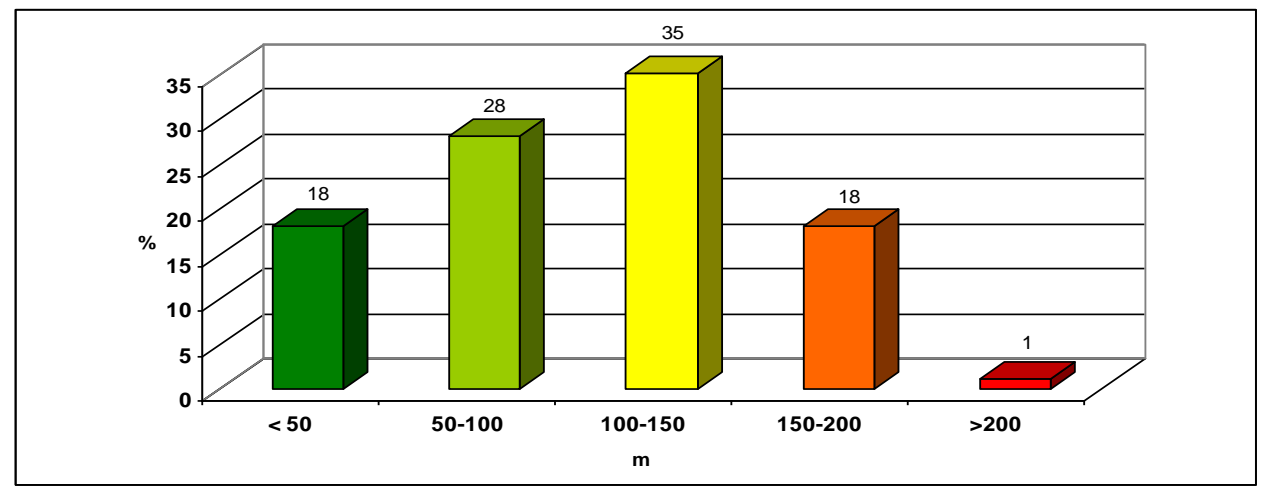

Figure 3. Histogram of surfaces by hypsometric classes ( $m$ )

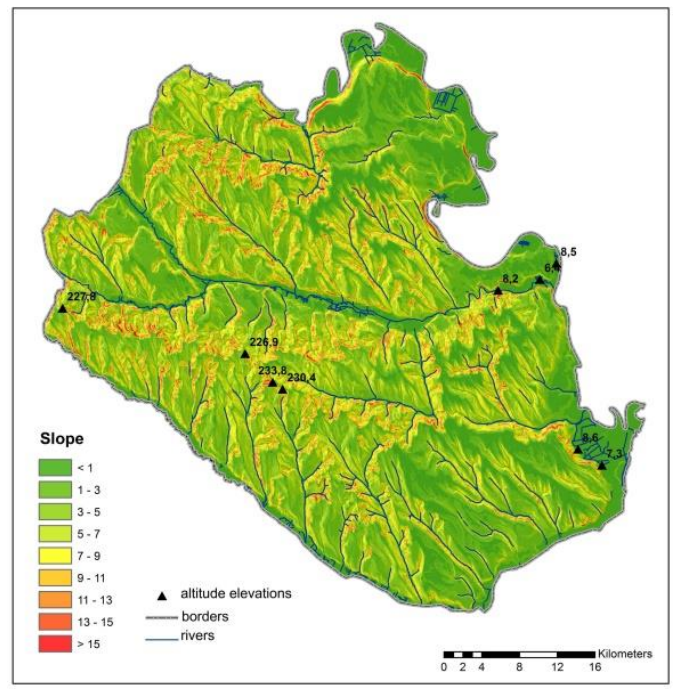

Figure 4. Slope map of the Lower Bic Plane

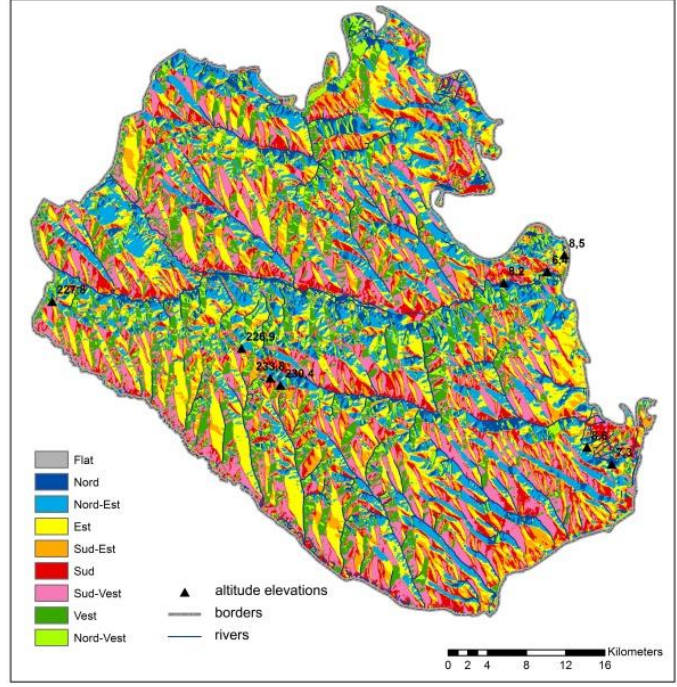

Figure 5. Slope orientation map of the Lower Bic Plain

\section{Methodology}

For the identification, mapping and analysis of the geomorphological processes, topomaps at the 1:25 000 scale, geological maps at the 1:200 000 and orthophotoplans with a resolution of $0.5 \mathrm{~m}$ were used (2007 edition), (Figure 6,7).

With the help of GIS technologies, which include a method widely used in science, especially in the field of geomorphology, we have had the opportunity to reproduce different aspects of the geomorphological processes and the forms created by their activity. In the analysis of the geomorphological parameters of the geomorphologic processes activity, we used the computer modeling (Hofer B., et al., 2009), thus creating the numerical model of the terrain and then calculating the morphometric indices. Maps of geomorphological processes were also created and their parameters were analyzed. 


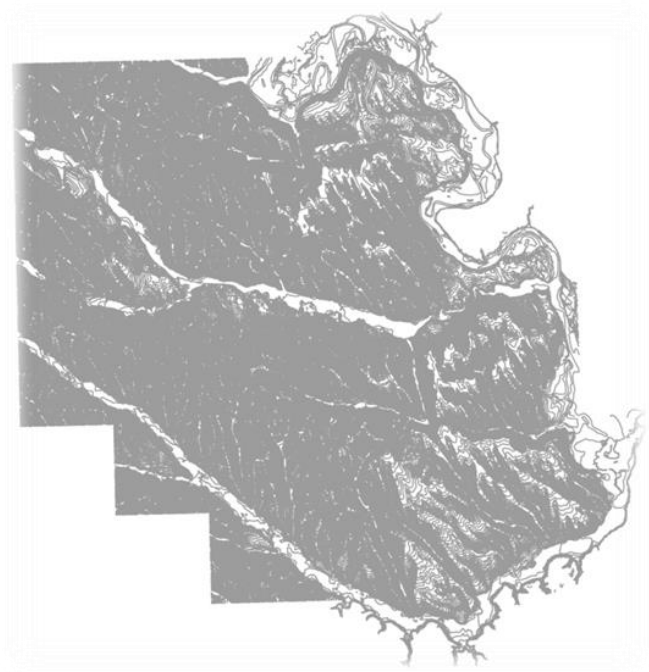

Figure 6. Contour lines (scale 1:25 000)

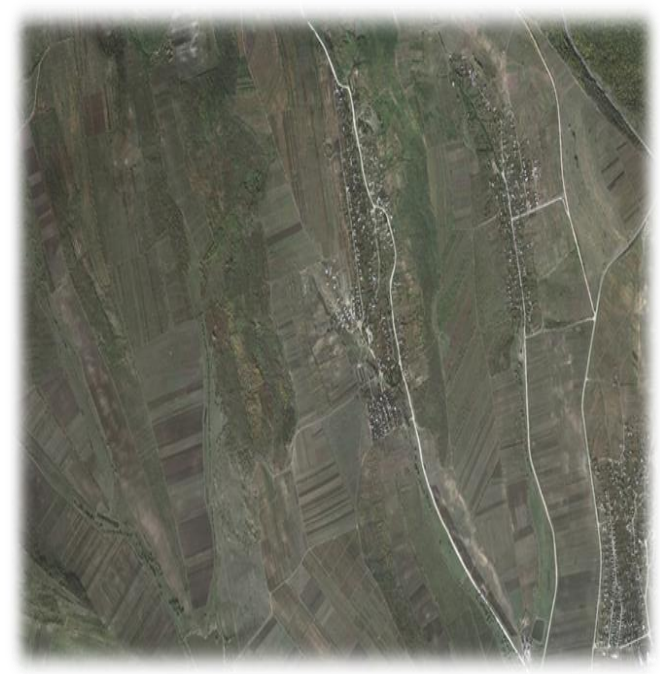

Figure 7. Orthophotoplans (rezoluţion 0,5*0,5)

\section{Results and discussions}

The most important processes that contribute to the degradation of the Lower Bic Plain fields are specific to the entire hilly area between the Prut and Dniester river and consist of soil erosion, gullies and landslides (Mihăilescu, Sochircă, et al., 2006).

\subsection{Geomorphological processes}

\section{Surface Soil erosion}

From the analysis carried out on the studies of the National Spatial Data Fund, cartographic materials and orthophotoplans (Table 1), we can say that approximately 21411.4 ha of land (which constitutes $9.38 \%$ of the total area of the plain) is affected by Erosion in the surface (Popusoi, Patriche, 2015).

Table 1. The weight of surface erosion in the Lower Bic

\begin{tabular}{|c|c|c|}
\hline Erozional classess & Surface $(\mathbf{H a})$ & Surface $\%$ \\
\hline Total surfaces & $\mathbf{2 2 8 1 7 4 , 0 0}$ & $\mathbf{1 0 0 , 0 0}$ \\
\hline Low eroded & 12041,82 & 5,28 \\
\hline Moderate eroded & 6834,79 & 3,00 \\
\hline High eroded & 2534,78 & 1,11 \\
\hline Total eroded soils & 21411,4 & 9,38 \\
\hline
\end{tabular}

Both, to the north and to the south of the researched territory one can notice that a more pronounced spread has the territories with low and moderately eroded surfaces, and a larger percentage of the high eroded surfaces are recorded in the central and the western part of the plain (Figure 8). The most widespread on the territory of the plain, with $5.28 \%$ of the total area of the territory is the low erosion, occupying about 12041.82 ha, being followed in decreasing 
order by moderate erosion with $3.00 \%$ of the territory and 6834.79 ha, but the high erosion has a share of only $1.11 \%$ or 2534.78 ha of the total area of the plain (Figure 9).

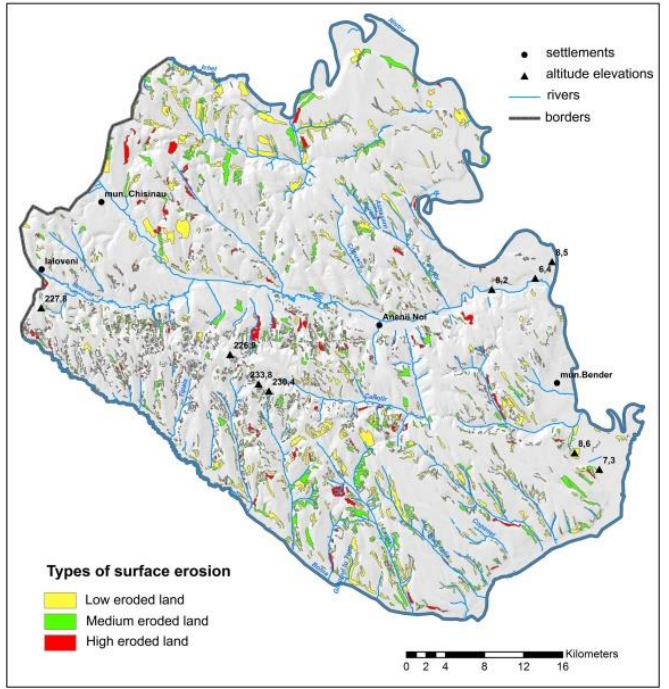

Figure 8. Soil erosion map of the Lower Bic Plain

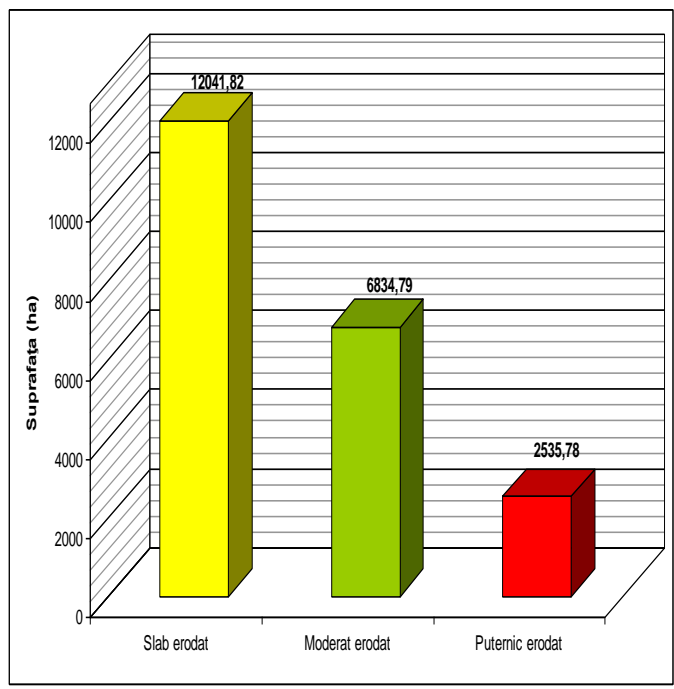

Figure 9. Soil eroded area bz intensitz classes

\section{Gullies}

On the Lower Bic Plain territory a number of 669 gullies (ravines) have been identified. The slope gullies represent 618 units and the valley gullies represent the rest of 51 units (Zagarovschi, Voloşchiuk, 2004). In the table below we represented some statistical data on both types of gullies (Table 2).

Table 2. The area occupied by gulliess in the Lower Bic

(After orthophotomaps, scale 1: 5000, 2007 edition)

\begin{tabular}{|c|c|c|c|c|c|c|}
\hline № & Gullies type & Number & $\begin{array}{c}\text { Surface } \\
(\mathrm{ha})\end{array}$ & $\begin{array}{c}\text { Smin } \\
\left(\mathrm{m}^{2}\right)\end{array}$ & $\begin{array}{c}\text { Smax } \\
(\mathrm{ha})\end{array}$ & $\begin{array}{c}\text { Smed } \\
\text { (ha) }\end{array}$ \\
\hline 1 & Slope gullies & 618 & 956,39 & 36,48 & 174,96 & 1,55 \\
\hline 2 & Valley gullies & 51 & 483,95 & 863,11 & 131,85 & 9,49 \\
\hline 3 & Total gullies & 669 & 1440,33 & 36,48 & 174,96 & 2,15 \\
\hline
\end{tabular}

The gullies spread on the plain have a non-uniform spread (Figure 10). Their distribution on a regional level depends on several factors and, considering the figure below, it is noticeable that the gullies are spread along the more steep slopes of the main rivers and their tributaries. But they are also spread on the slopes of the secondary valleys (also this processes is noticed on steep slopes with smaller lengths). 


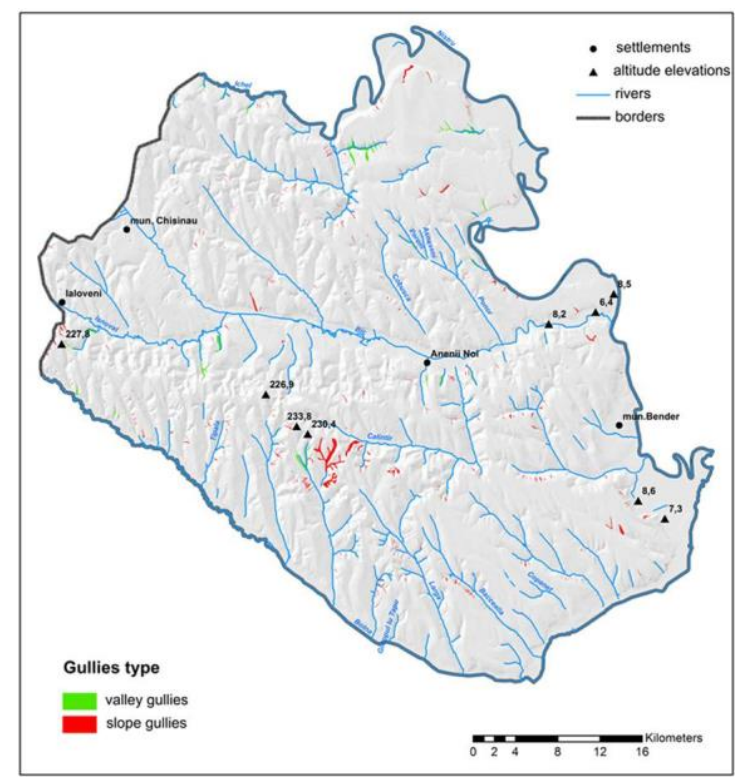

Figure 10. Spreading of the gullies in the Lower Bic Plain

Taking into account the fact that the slope and the altitude are the most important morphometric parameters of the relief, the correlation of the flowing process for these two parameters has been established. So, on the altitudes ranging between $50-100 \mathrm{~m}$ are spread most of the gullies. The slope gullies have a share of $27.34 \%$ (394.20 ha) of the total area affected by gullies, and the valley gullies have a share of $17,73 \%$ (255.31 ha). After the altitudes ranging from 50 to $100 \mathrm{~m}$, follow the altitudes ranging from 100 to $150 \mathrm{~m}$, here the area occupied by the slope gullies is of 527.59 ha, with a percentage of $27.37 \%$ (394.2 ha) and the percentage of the valley gullies of $9.26 \%$. On the surfaces with an altitude up to $50 \mathrm{~m}$ the valley gullies have a share of $6.15 \%$ ( 88.57 ha) comparing with the slope gullies with a share of $3.58 \%$ (51.55 ha). On the surfaces with the 150-200 altitudes, with a big difference are registered the slope gullies with $7.80 \%$ (112.33 ha) comparing with $0.46 \%$ (6.67 ha) that are occupied by valley gullies (Figure 11).

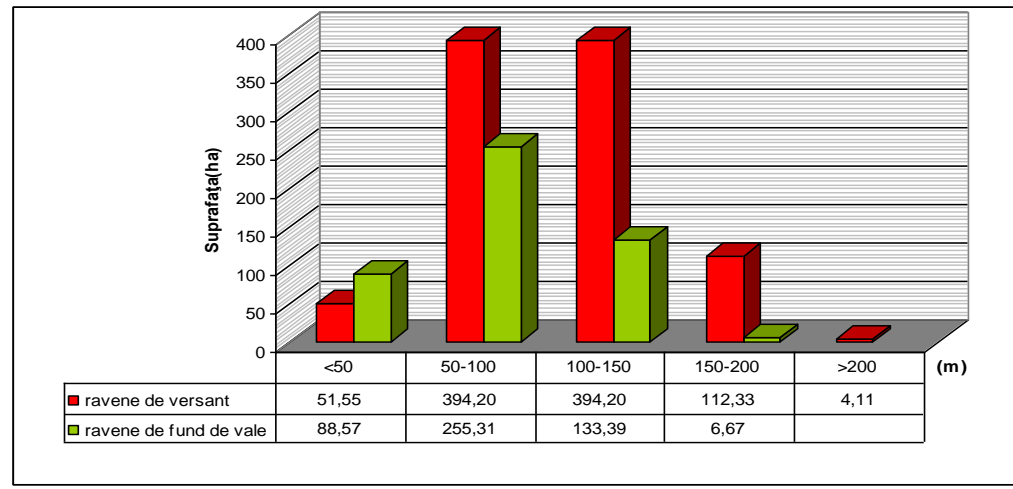

Figure 11. The weight of the gullies type on altitude classes in the Lower Bic Plain 
Depending on the slope, four other categories of surfaces affected by gullies have been delimited. Thus, the most affected by gullies are the slopes ranging from $5-9^{\circ}$, with a total percentage of $47.95 \%$ of the total surface, which is an area of 690.51 ha. Then follow slopes ranging between $3-5^{\circ}$ and $9-11^{\circ}$, representing $16.48 \%$ (237.39 ha) and $14.97 \%$ (215.54 ha) respectively of the total surface of the gullies. Areas with slopes up to $3^{\circ}$ have a total percentage of $10.37 \%$ (149.33 ha), and the slopes exceeding $11^{\circ}$ reach a slightly smaller percentage of approximately $10.22 \%$ (147.58 ha) of the total area affected by the gullies (Figure 12).

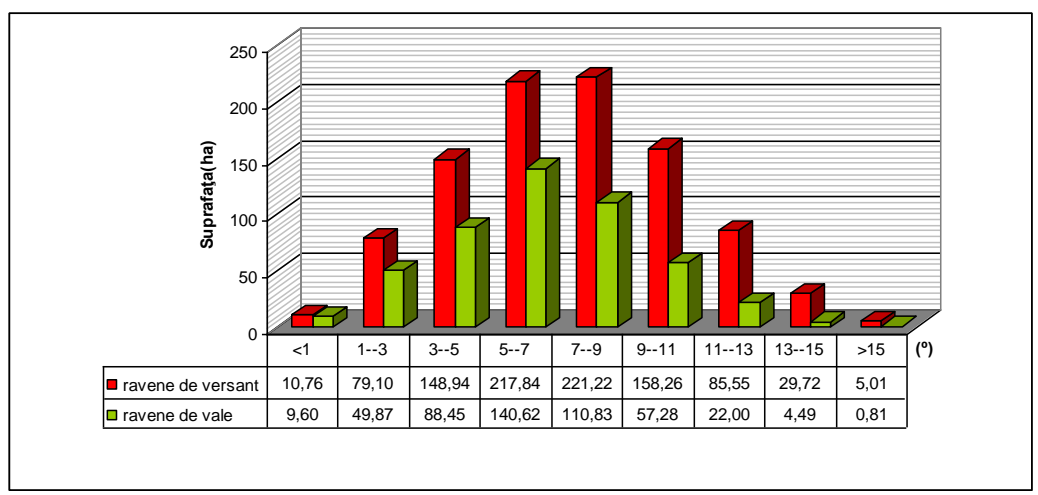

Figure 12. The weight of the gullies type on slope classes in the Lower Bic Plain

\section{Landslides}

On the researched territory 211 landslides have been identified (Table 3), their total surface being 2138,03 ha.

Table 3. Landslides surface (after orthophotomaps, 1: 5000, 2007 edition)

\begin{tabular}{|c|c|c|c|c|c|c|c|c|}
\hline $\begin{array}{c}\text { № } \\
\text { crt. }\end{array}$ & $\begin{array}{c}\text { Land- } \\
\text { slides }\end{array}$ & Number & $\begin{array}{c}\text { Sur. } \\
\text { (ha) }\end{array}$ & $\begin{array}{c}\text { \% (from } \\
\text { landslides) }\end{array}$ & $\begin{array}{c}\text { \% (from } \\
\text { plain } \\
\text { surface) }\end{array}$ & $\begin{array}{c}\text { Smin } \\
\text { (ha) }\end{array}$ & $\begin{array}{c}\text { Smax } \\
\text { (ha) }\end{array}$ & $\begin{array}{c}\text { Smed } \\
\text { (ha) }\end{array}$ \\
\hline 1 & active & 109 & 737,88 & 34,51 & 0,32 & 0,23 & 50,50 & 6,77 \\
\hline 2 & stable & 102 & 1400,15 & 65,49 & 0,61 & 0,52 & 117,79 & 13,73 \\
\hline 3 & Total & 211 & 2138,03 & 100,00 & 0,94 & 0,23 & 117,79 & 10,13 \\
\hline
\end{tabular}

The distribution of landslides in the investigated territory is non-uniform. Most landslides are recorded on the slopes of the plain, so these processes are more concentrated in the N-S direction with a rare spread to NV and SE (Figure 13). Altitude being an important factor in triggering the sliding process, below is a graphical representation of the association of the landslides with the altitudinal steps. A high frequency of active landslides of over $12 \%$ and $16 \%$ is recorded in the altitude range of $100-150 \mathrm{~m}$ and 50-100 m. Instead, at altitudes less than $50 \mathrm{~m}$, only $6.23 \%$ of the landslides, of which $2.73 \%$ occupy the active ones and the stabilized ones are only $3.5 \%$.

The largest stable landslides are found at altitudes between 50-150 m and hold a share of over $50 \%$. The lowest value is registered on the altitude class of over $200 \mathrm{~m}$, which occupies a share of less than $1 \%$ of the total landslides, but here a higher share, about 7 times, occupies the active landslides (Figure 14). 


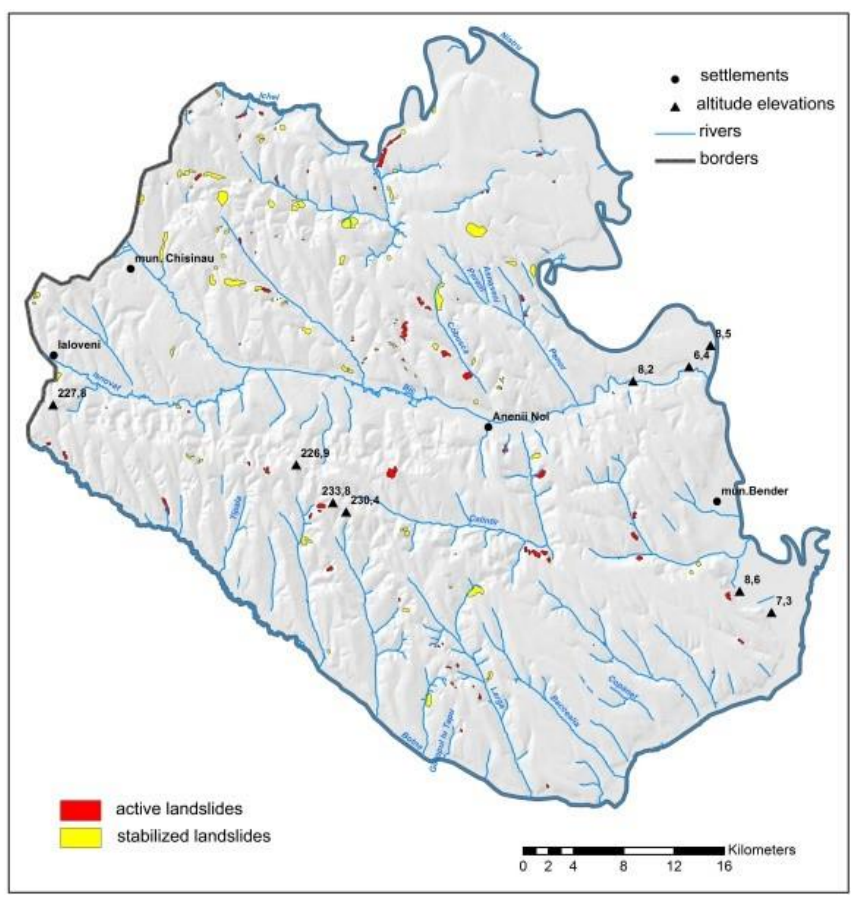

Figure 13. Map of the landslides spreading in the Lower Bic Plane

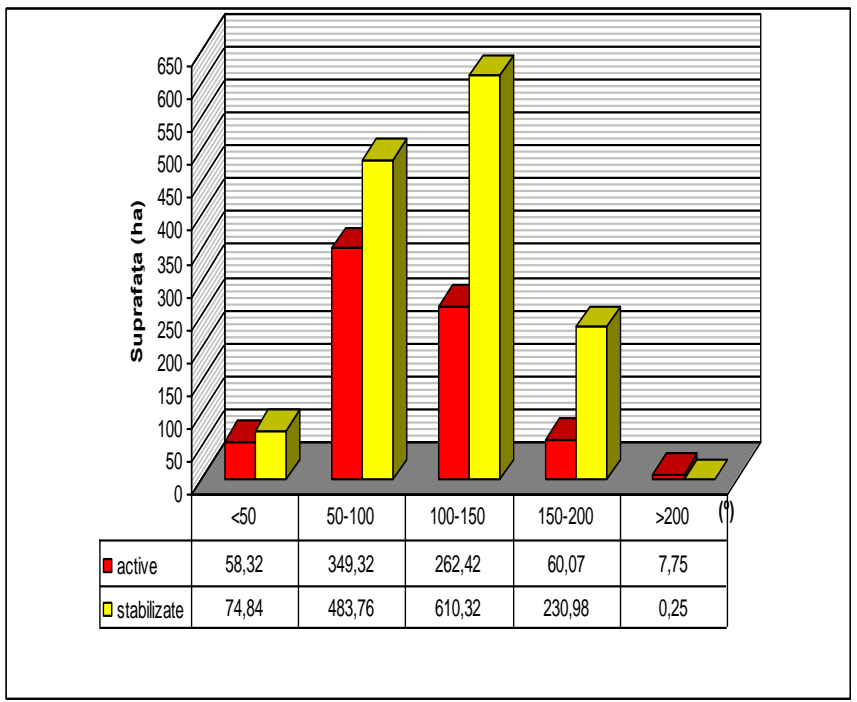

Figure 14. Surfaces occupied by each landslide type on altitudinal classes

Taking into account the relationship between landslides and the hill slope on which they are distributed, we notice that most of the slides are spread on slopes ranging from $5^{\circ}$ to $13^{\circ}$. The $7-9^{\circ}$ and $9-11^{\circ}$ classes have a maximum favorability for all types of landslides and represents a total weight of $47.75 \%$ of the total area of landslides in the researched area (Figure $15)$. 
The smallest share is occupied by the slopes up to $3^{\circ}$, here the share of landslides reaches $7.79 \%(166.51 \mathrm{ha})$, and the slopes ranging $13-15^{\circ}$ and those above $15^{\circ}$, here the landslides represent $5.89 \%$ (125.93 ha) and $2.38 \%$ (50.85 ha), respectively.

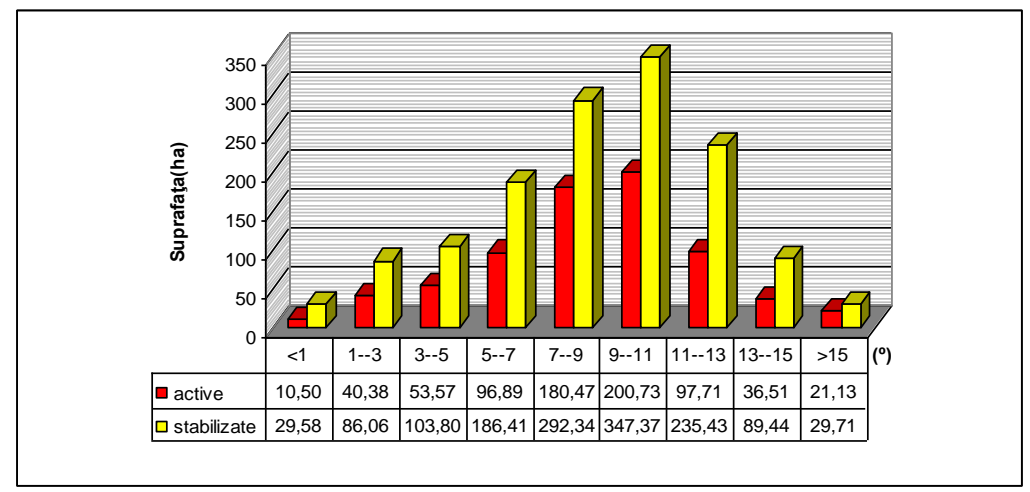

Figure 15. Surfaces occupied by each landslide type on slope classes

\section{Conclusions}

The spatial distribution of geomorphological processes reveals their greater predominance in the east and west, and lower in the north and south parts of the region. Many degraded areas have been set up by works carried out by 1990. However, anthropic activity has created conditions that led to the resumption of these processes.

Thus, about $10 \%$ of the total area of the plain is affected by surface erosion, of which more than half are occupied with soils with a low erosion process. Even if the largest areas are occupied by low eroded soils, this does not exclude the fact that, in the absence of suitable fitting works, all of these areas will pass into the category of high eroded soils.

It is also concluded that the areas most affected by gullies are the areas located at altitudes between 50-100 m, followed by the surfaces located at altitudes ranging between 100$150 \mathrm{~m}$; this fact tells us that these surfaces need increased attention in creating a management plan in order to mitigate this process.

As far as the sliding process is concerned, it has been found, after the landslide repartition, that the most affected areas are located in the NS direction. Here it has been found that the most favorable altitudes for the development of this process are the altitudes between $100-150 \mathrm{~m}$ and the most favorable slope would be the surfaces with slope ranging between $9^{\circ}$ and $11^{\circ}$.

\section{References}

1. Canţîr A., 2016. Cîmpia Bîcului Inferior-Analiza morfometrică şi morfologică. Tipogr. „Elan Poligraf". Academicia Leo Berg - 140 years: Collection of Scientific Articles, Bender: EcoTiras. P. 127-130.

2. Donisă I., Boboc N., 1994. Geomorfologie. Editura LUMINA, Chişinău, 21-24.

3. Mihăilescu C., Sochircă V. ș.a., 2006. Mediul Geografic al Republicii Moldova. Resursele Naturale. Editura Ştiința, Chişinău. 
4. Popuşoi T., Canţîr A., Sîrodoev Gh., 2012. Evaluarea parametrilor morfometrici în rezervaţia peisagistică „Pădurea Hîrbovăț’” cu suportul geoinformaţional. Editura Elena-VI, Chişinău. În Buletinul Institutului de Geologie şi Seismologie al Academiei de Ştiinţe a Moldovei, Nr.2. p.110-115.

5. Popuşoi Tatiana, Patriche Cristian-Valeriu „Quantitative estimation of soil erosion in the Larga catchment - Tigheci Hills", GEOREVIEW-Scientific Annals of Stefan cel Mare Universitz of Suceava, Geography Series, vol25, No1 (2015), p.13-22;

6. Zagarovschi V., Voloşchiuk M., 2004. "Formele de manifestare a eroziunii liniare şi metodele de combatere", Eroziunea Solului, Ed. Pontos, Chişinău.

7. Hofer B., et all, 2009. Composing Models of Geographic Physical Processes. Spatial Information Theory,9th International Conference, COSIT, Aber Wrac'h, France, Proceedings, Series: Vol. 5756, p. 421-435 